\title{
Inflectional Morphology in Arabic and English: A Contrastive Study
}

\author{
Muayad Abdul-Halim Ahmad Shamsan ${ }^{1,2} \&$ Abdul-majeed Attayib ${ }^{3}$ \\ ${ }^{1}$ College of Science and Arts, University of Bisha, Saudi Arabia \\ ${ }^{2}$ Faculty of Arts, Omdurman Islamic University, Sudan \\ ${ }^{3}$ English Language Centre, Umm AlQura University, Saudi Arabia \\ Correspondence: Muayad Abdul-Halim Ahmad Shamsan, M. A Lecturer, College of Science and Arts, \\ University of Bisha, Saudi Arabia. E-mail: muayadhalim@yahoo.com
}

Received: January 14, 2015 Accepted: February 12, 2015 Online Published: March 29, 2015

doi:10.5539/ijel.v5n2p139 URL: http://dx.doi.org/10.5539/ijel.v5n2p139

\begin{abstract}
This paper investigates Arabic and English inflectional morphology with a view to identifying the similarities and differences between them. The differences between the two languages might be the main reason for making errors by Arab EFL learners. Predicting the sources of such errors might help both teachers and learners to overcome these problems. By identifying the morphological differences between the two languages, teachers will determine how and what to teach, on the one hand, and students will know how and what to focus on when learning the target language, on the other.
\end{abstract}

Keywords: inflectional morphology, modern standard Arabic, contrastive analysis

\section{Introduction}

\subsection{Inflectional Morphology}

Inflectional affixes are those which are affixed to words to indicate grammatical function. Spencer, (1991, p. 21) points out "Inflectional operations leave untouched the syntactic category of the base, but they too add extra elements. These are elements of meaning (for example, tense, aspect, mood, negation and so on) and also grammatical function." The grammatical function of a word in a sentence manifests itself clearly in terms of either word inflectional ending as in Arabic or word position in a sentence as in English. It has been pointed out by (Thakur, 1997, p. 86) that "The syntactic relationship that a word has with the other words in the sentence manifests itself in its inflectional endings and not in the place that it occupies in relation to the other words in that sentence." Arabic language is one of the inflectional languages, whereas, English shows only a few features of these languages.

\subsection{Modern Standard Arabic}

There is a little difference between Classical Arabic (CA) and Modern Standard Arabic (MSA). The former is the language of the Holy Quran and the latter is currently used in the Arab world. Ryding, (2005, p. 4) says "In terms of linguistic structure, CA and MSA are largely but not completely similar." Though, there are different dialects of Arabic that are spread all over the Arab countries, the official language that is used by all of them is MSA. It is the language of literature, media and education.

\subsection{Contrastive Analysis (CA)}

Fisiak (1981, p. 1) defines CA as a linguistic discipline that is concerned with comparing two or more systems of languages to determine similarities and differences between them. Interlingual errors made by students usually stem from mother tongue interference. CA helps teachers predict these errors and present some remedial solutions to these problems before they occur.

\subsection{Objectives of the Study}

This study includes both comparing and contrasting Arabic and English inflectional morphology to find out similarities and differences between them. It is hoped that this study will provide some solutions to the linguistic problems that Arab EFL learners face due to the differences between the two languages in terms of inflectional morphology. Both teachers and students will be acquainted with these problems and plan for their solutions. 


\subsection{Limitation of the Study}

This study is limited to Arabic and English inflectional morphology. However, its theoretical findings and results will help not only teachers and EFL Arab learners, but also syllabus designers to reconsider areas of difficulty that cause problems to students in inflectional morphology.

\subsection{Methodology}

This study is largely a theoretical study. Different books on Standard Arabic and English morphology and syntax have been utilized. Then, a descriptive method has been used to describe the data using the principles of contrastive linguistics.

\section{Arabic Words}

Arabic words consist of one or more morphemes. Unlike English, the morphemes in Arabic content words are discontinuous. Watson, $(2002$, p. 3) points out "One of the main distinguishing features of Semitic languages is their root-and-pattern morphology." The root in Arabic language is consonantal and it cannot stand on its own as a word. It indicates meaning but it needs the support of a pattern, i.e., one or more vowels, to form a word. Function words, pronouns and loanwords are regarded as solid stems because "they cannot be reduced or analyzed into the root-pattern paradigm" (Ryding, 2005, p. 50). To derive or inflect words from that root, vowels are usually inserted into it. In other cases consonants can be affixed to that root to derive other words. The root consonant $q-t-l$ (Note 1) indicates something related to killing. Table (1) shows different words related to this meaning.

Table 1 . Words related to the same meaning with the same consonantal root

\begin{tabular}{llll}
\hline Word & Meaning & Word & Meaning \\
\hline Qatal & kill + perfective & Qātala & fight + perfective \\
yaqtul & kill + imperfective & qātil & killer/mortal \\
Puqtul & kill (imperative) & qatl & killing \\
qatīl & killed/martyr/assassinated & taqātal & fight (one another) \\
maqtūl & killed/martyr/assassinated & qutila & be + killed \\
\hline
\end{tabular}

\subsection{Verb Structure}

The grammatical categories that pertain to verbs in Arabic are: tense, number, person, mood, gender and voice. There is an agreement between the verb and the subject of the sentence in terms of number, person and gender. (Ryding, 2005, p. 438) argues that "agreement markers ensure that the verb inflects in accordance with the nature of its subject." The consonants in $q-r$-? indicate something related to reading. Table (2) presents different sound triliteral verb forms in the past tense that consist of the consonantal root $q-r-P$, the vowel pattern $-a-a$ - and the suffixes that carry the inflectional markers for number, person and gender. It should be noted that past tense verbs don't take prefixes to inflect.

Table 2. Past tense verbs with the same consonantal root conveying related meaning

\begin{tabular}{|c|c|c|c|}
\hline Word & Number & Person & Gender \\
\hline qara?tu & Sg. & $1^{\text {st }}$ & Masc./Fem. \\
\hline qara? $2 \bar{a}$ & Dual/Pl. & $1^{\mathrm{st}}$ & Masc./Fem. \\
\hline qara?a & Sg. & $3^{\text {rd }}$ & Masc. \\
\hline qara?at & Sg. & $3^{\text {rd }}$ & Fem. \\
\hline qara?ā & Dual & $3^{\text {rd }}$ & Masc. \\
\hline qara ?atā & Dual & $3^{\text {rd }}$ & Fem. \\
\hline qara $?_{\bar{u}}$ & Pl. & $3^{\text {rd }}$ & Masc. \\
\hline qara?na & Pl. & $3^{\text {rd }}$ & Fem. \\
\hline qara?ta & Sg. & $2^{\text {nd }}$ & Masc. \\
\hline qara?ti & Sg. & $2^{\text {nd }}$ & Fem. \\
\hline qara itumā & Dual & $2^{\text {nd }}$ & Masc./Fem. \\
\hline qara Ptum & Pl. & $2^{\text {nd }}$ & Masc. \\
\hline qara?tun & Pl. & $2^{\text {nd }}$ & Fem. \\
\hline
\end{tabular}


Table (3) presents different forms of the sound triliteral verb in the present tense that consist of the consonantal root $c c-c(q r-P)$. The prefixes $? a$ - and $n a$ - carry the inflectional marker for person, number, and gender. The prefix $y a$-carries information about third person. If the verb has the prefix $t a$-and no suffix is attached to it, this prefix is the sign of singular, third person feminine or singular second person masculine. If the prefix attached to the present form provides complete information and clear image about the subject, a suffix will not be added to that form (Al-Nahāas, 1995, p. 45). The first four verbs in table (3) illustrate this point. Hence, the combination of both the prefix and the suffix carries information about person, number and gender.

Table 3. Present tense verbs with the same consonantal root conveying related meaning

\begin{tabular}{|c|c|c|c|}
\hline Word & Number & Person & Gender \\
\hline Paqra? & $\mathrm{Sg}$. & $1^{\mathrm{st}}$ & Masc./Fem. \\
\hline naqra? & Dual/Pl. & $1^{\text {st }}$ & Masc./Fem. \\
\hline yaqra? & Sg. & $3^{\text {rd }}$ & Masc. \\
\hline taqra? & Sg. & $3^{\text {rd }}$ & Fem. \\
\hline yaqra $\stackrel{\imath}{a}(n)$ & Dual & $3^{\text {rd }}$ & Masc. \\
\hline taqra? $\bar{a}(n)$ & Dual & $3^{\text {rd }}$ & Fem. \\
\hline yaqra $\widehat{\imath} \bar{u}(n)$ & Pl. & $3^{\text {rd }}$ & Masc. \\
\hline yaqra?na & Pl. & $3^{\text {rd }}$ & Fem. \\
\hline taqra? & Sg. & $2^{\text {nd }}$ & Masc. \\
\hline taqra ?inn & Sg. & $2^{\text {nd }}$ & Fem. \\
\hline taqra $P \bar{a}(n)$ & Dual & $2^{\text {nd }}$ & Masc./Fem. \\
\hline taqra?̄ü(n) & Pl. & $2^{\text {nd }}$ & Masc. \\
\hline taqra?na & Pl. & $2^{\text {nd }}$ & Fem. \\
\hline
\end{tabular}

The imperative form of the sound triliteral verb in Arabic has the structure $c v c c v c$. The suffixes added to this structure indicate the grammatical categories of person, number and gender.

Table 4. Verbs with the same consonantal root conveying imperative meaning

\begin{tabular}{lll}
\hline Word & Number & Gender \\
\hline Piqra? & Sg. & Masc. \\
Piqra $\bar{\imath}$ & Sg. & Fem. \\
Piqra $\bar{a}$ & Dual & Masc./Fem. \\
Piqra $\bar{\imath}$ & Pl. & Masc. \\
Piqra $\bar{\imath}$ na & Pl. & Fem. \\
\hline
\end{tabular}

\subsubsection{Morphological Categories: Person, Number and Gender}

The first person is one or more who speak/s. The second person refers to one or more one speaks to and the third person refers to animate or inanimate being/s one speaks about (Al-Naḥās, 1995, p. 49). Arabic verbs are conjugated for three numbers: singular, dual and plural. The suffixes $-t u$ and $-n \bar{a}$ attached to the past tense verb and the prefixes $P a$ - and $n a$ - attached to the present tense verb refer to the first person and they indicate no gender distinction. Gender is manifested in verbs that refer to second or third person. The first person is gender neutral (Ryding, 2005, p. 438). The tables above carry as much as necessary information on how the verbs are conjugated to carry person, number and gender.

\subsubsection{Tense}

A verb lexeme in Arabic has three forms: past, present and imperative. The former two forms along with different particles can be used to express different tenses in Arabic. Haywood and Nahmad, (1965, p. 96) claim that there are two main tenses in Arabic language: perfect and imperfect. Wright, (1967, pp. 1-24) discusses the two basic Arabic tenses and the different states in which they occur. The trilileral verb forms of these two tenses have been discussed previously. The future tense form is formed by adding the prefix $s$ - or the particle sawfa, whose English counterpart is the modal auxiliary will or be going to, to the present form (Note 2). 


\subsubsection{Mood}

The grammatical feature of verbs that signals modality is called mood. The present tense verbs in Arabic language are marked for mood. The vowel suffixes $-u,-a$ are added to the present tense verb to indicate the indicative and subjunctive moods respectively as in (1).

$$
\begin{array}{llccl}
\text { 1. a. yadhhabu } & \text { al-tālibu } & \text { Pila } & \text { al-madrasati } & \text { kulla șabāh } \\
\text { went } & \text { the-studetn } & \text { to } & \text { the-school } & \text { every morning } \\
\text { ind. } & \text { nom. } & \text { gen. } &
\end{array}
$$

$\begin{array}{ccccl}\text { b. lan } & \text { Pathhaba } & \text { Pila } & \text { al-madrasati } & \text { ghadan } \\ \text { not } & \text { I-go } & \text { to } & \text { the-school } & \text { tomorrow } \\ & \text { sub. } & & \text { gen. }\end{array}$

The jussive mood is realized by means of zero suffix. That is, no suffix is added to the verb after the final consonant as in (2) (Note 3).

$\begin{array}{cccccc}\text { 2. lam } & \text { yathhab } & \text { al-tâlibu } & \text { Pila } & \text { al-madrasati } & \text { Pams } \\ \text { not } & \text { go } & \text { the-student } & \text { to } & \begin{array}{c}\text { the-school } \\ \text { gen. }\end{array} & \text { yesterday } \\ & \text { jus. } & \text { nom. } & & \text { gen. }\end{array}$

\subsubsection{Voice}

Arabic verbs are conjugated to indicate the passive voice. The passive voice in Arabic is mainly a morphological operation. The past and present forms of the Arabic verb are changed into passive by simply changing the vowel pattern. The vowel that follows the first consonant is changed into $-u$ - in both forms and the one that precedes the last consonant is changed into $-i$ in the past form and $-a$ in the present form (Note 4 ).

\subsection{Nouns}

Arabic nouns are marked for four grammatical categories: case, number, gender and definiteness.

\subsubsection{Case}

In Arabic, nouns have three cases: nominative, accusative and genitive. These three cases are indicated by changing the vowel that occurs after the final consonant (Haywood \& Nahmad, 1965, p. 33).

3. ja?a al-tālibu

came the-student (nom.)

The student came.

4. ra?ytu al-țāliba

saw-I the-student (acc.)

I saw the student.

5. ghadiba al-mudarisu Cala at-tālibi

got angry the teacher with the-student

nom. gen.

The teacher got angry with the student.

In $(3,4$, and 5), the final consonant $b$ in $a l$-tatilib is followed by $u, a$ and $i$ to indicate the nominative, accusative and genitive cases respectively. The translation of case names, as stated by Haywood and Nahmad, (1965, p. 33) "is sometimes misleading." Many Arab students make errors when they translate sentences that have case endings. Since the case marker is not necessarily to be added in written Arabic, the errors might not appear clearly. But the errors will clearly be displayed with nouns whose case marker are not kasrah (-i), fatha (-a) or damma $(-u)$ such as the dual form, the sound masculine plural and the five nouns.

\subsubsection{Number}

In as far as number is concerned, nouns in Arabic have three forms: singular, dual and plural (Note 5). The majority of Arabic nouns consist of three consonantal roots. The dual and plural forms are made by means of affixation. The basic meaning of a word is indicated by the consonantal root and the dual form of a noun is made 
by adding the inflectional suffixes $-\bar{a} n$ in the nominative case and -ayn in the accusative and genitive cases as in (6.b) and (7.b) (Note 6).

$$
\begin{aligned}
& \text { 6. a al-kitābu jadīdun } \\
& \text { the-book- nom. new }
\end{aligned}
$$

The book is new.

b. al-kitābān jadīiān

the-book-two-nom. new-two

The two books are new.

$$
\begin{array}{cl}
\text { 7. a ishtaraytu al-kitāba } \\
\text { bought-I } & \text { the-book- acc. }
\end{array}
$$

I bought the book.

$$
\begin{aligned}
& \text { b. ishtaraytu al-kitābayn } \\
& \text { bought-I the-book-two- acc. } \\
& \text { I bought the two books. }
\end{aligned}
$$

Feminine nouns are made dual by applying the previous rule to make the dual form of a noun. In addition, the gender suffix $-h$ is changed into $-t$ e.g. țălibah (a student-fem.) becomes țâlibatān (student-fem.-dual-nom.) or țälibatayn (student-fem.-dual-acc./gen.).

The plural form in Arabic has three kinds: broken plural, sound masculine plural and sound feminine plural. Arab grammarians have presented different patterns for the broken plural. The most common of which can be categorized as follows:

1. The broken plural form of a noun is sometimes made by means of infixing different vowel pattern to the consonantal root e.g., kitāb 'a book', kutub 'books'.

2. In some cases, it is made plural by means of changing the vowel pattern and prefixing a consonant e.g., qalam 'a pen', ?qlām 'pens'.

3. Other broken nouns can be made plural by changing the vowel pattern and adding a suffix, e.g., ghulām 'boy', ghilmān 'boys'.

4. Some nouns become plural by means of prefixing, suffixing and changing the vowel pattern, e.g., $\{a m \bar{u} d$ 'pillar', Pa Smidah 'pillars'.

5. Others are made plural by deleting the ultimate part of a noun that indicate feminine gender and changing the vowel pattern such as ghurfah 'a room', ghuraf'rooms' and raqabah 'neck', riqāb 'necks'.

6. Nouns with a root of two consonants and a long vowel $-\bar{a}$ - occurs between them such as $b \bar{a} b$ and $n \bar{a} b$ are made plural by prefixing the consonant ${ }^{2}$-, and infixing the consonant $w$ or $y$ before the long vowel. Thus, $b \bar{a} b$ and $n \bar{a} b$ become $? b w \bar{a} b$ and $2 n y \bar{a} b$ in their plural forms.

The sound plural form of the masculine noun is made by adding the suffix $-\bar{u} n$ to the singular form to indicate the nominative case and the suffix $-\overline{i n}$ to indicate the accusative or genitive cases. For example, muslim becomes muslimün (nom.) and muslimīn (acc. or gen.). The sound feminine plural is made by putting the suffix -ät in place of the suffix $-a h$. The vowels $-u$ and $-i$ that are added to the plural form of the sound feminine plural are to indicate the noun case. For example, the plural form of the word muslimah is either muslimātu (nom.) or muslimäti (acc. or gen.).

\subsubsection{Gender}

Arabic nouns both animate and inanimate are either masculine or feminine. It is easy to distinguish between them because the feminine nouns usually end with the feminine marker that is called ta 2 marbut tah which is pronounced as $h$ when the speaker pauses such as sayyarah or al-sayyarah. It is pronounced as $t u$ in the nominative case, al-sayyaratu, $t a$ in the accusative case al-sayyarata and $t i$ in the genitive case al-sayyarati. When the definite prefix is not attached to the noun, the noun ends with tanwin, -un for nom. case, -an for acc. case and -in for gen. case.

There are nouns that do not end with the feminine marker. These words are either words that refer to female people such as ?ukht, 'sister' or proper names of countries and cities mișr, 'Egypt', parts of the body such as yad, 
'hand', some other nouns are treated as feminine for no apparent reason such as shams, 'sun' and dār, 'house' and collective nouns (Haywood \& Nahmad, 1965, pp. 27-28; Thackston, 1994, p. 8). Fehri, (2012, p. 300) claims that collective nouns like nahl, 'bees', naml, 'ants', and Pabqa $r$, 'cows' "are ambiguous in terms of their gender". It seems that these nouns which refer to animal category are problematic for speakers of English who learn Arabic when they are in the plural form. However, they pose no problem when they are in their singular form because the feminine marker is overt. The singular forms of these nouns are nahlah, 'a bee', namlah, 'an ant', and baqarah, 'a cow' respectively.

For the reason that gender distinction in English nouns hardly occurs, Arabic nouns pose some challenges for AFL learners. These learners might make some morphosyntactic errors in their Arabic performance when they translate from English into Arabic, write Arabic essays or speak Arabic.

\subsubsection{Definiteness}

Arabic language is different from English in terms of definiteness. Arabic has definite article which is prefixed to a noun, but indefinite articles do not exist in Arabic. Haywood and Nahmad, (1965, p. 22) state "the presence of nunation at the end of a noun indicates indefiniteness". Thus, waladun means 'a boy', and al-waladu means 'the boy'. In phrases where a noun is followed by an adjective, the adjective agrees with the noun in terms of definiteness, gender and number as in (8).

$$
\begin{aligned}
& \text { 8. a. waladun țawīlun } \\
& \text { boy-indef. tall-indef. (a tall boy) } \\
& \text { b. al-waladu al-țawīlu } \\
& \text { the-boy the-tall (the tall boy) }
\end{aligned}
$$

When the definite article that is attached to the adjective as in (8.b) is deleted, the phrase becomes a nominal sentence as in (9).

$$
\begin{aligned}
& \text { 9. al-waladu țawīlun } \\
& \text { the-boy tall-indef. (The boy is tall.) }
\end{aligned}
$$

\subsection{Pronouns}

Pronouns in Arabic are marked for person, number, gender and case. As for their form, they are divided into two types: independent pronouns and dependent pronouns. Independent pronouns are those which can stand on their own as words, but dependent pronouns cannot stand alone. They occur as suffixes or prefixes. Arabic, like English, has two first person pronouns. The two languages differ in terms of the second and the third person pronouns. In Arabic, there are five second person pronouns that are expressed in English by means of one pronoun 'you'. The third person pronouns in Arabic are also more than their English counterparts. In addition, there is no neuter pronoun in Arabic. These independent pronouns as claimed by Ryding, (2005, pp. 299-300) can function as a subject of a verb, a subject or a predicate of a verbless sentence and as a copula. Furthermore, an independent pronoun can function as both a subject and a copula. Table (5) displays a detailed description on how independent pronouns are marked for number, person and gender.

Table 5. Arabic independent pronouns

\begin{tabular}{lll}
\hline Pronoun & & Meaning \\
\hline First Person & Panā & I \\
& naḥnu & We \\
\hline Second Person & Pnta & you-sg.-masc. \\
& Pnti & you-sg.-fem. \\
& Pntumā & you-dual-masc./fem. \\
& Pntum & you-pl.-masc. \\
& Pntun & you-pl.-fem \\
\hline Third Person & Huwa & he/it-masc. \\
& Hiya & she/it-fem. \\
& Humā & they-dual-masc./fem. \\
& Hum & they-pl.-masc. \\
& Hun & they-pl.-fem. \\
\hline
\end{tabular}


Dependent pronouns are bound morphemes that are suffixed to verbs, prepositions or nouns. First and third person pronouns can be attached to the past tense, present tense and to the imperative forms of the verb. However, second person pronouns can only be attached to the past and present forms of the verb. Excluding the third person singular feminine possessive pronoun $-h \bar{a}$, if the noun to which the third person possessive pronoun is attached is in the nominative or accusative case, the attached pronoun starts with $-h$ that must be followed with $-u$. If the noun is in the genitive case the attached pronoun starts with $-h$ followed by $-i$. Thackston, $(1994$, p. 40) states: "The 3rd-person enclitics, with the exception of the 3rd fem. sing. - $h \bar{a}$, harmonize with the vowel that precedes immediately. When the immediately preceding vowel is $u$ or $a$. Dependent pronouns can also occur as prefixes" (Note 7).

Independent pronouns are usually used in the nominative case because they function as a subject of a sentence, but the attached pronouns are commonly used in the accusative case when they serve as objects or in the genitive case when they serve as possessive pronouns. The prefixes $P a-, n a-, y a-$ and $t a$ - are attached to Arabic present form of the verb and the Arab grammarians called Pahrufu almuḍära 9 ah in verbs such as Paqra?, naqra?, yaqra? and taqra? can be considered as attached/dependent pronouns that indicate grammatical categories.

\subsection{Adjectives}

As for number, gender, case and definiteness, Arabic adjectives agree with the nouns they modify. Nevertheless, the following cases are exceptions:

1. When the adjective functions as a predicate in a verbless sentence, the adjective does not agree with the noun it describes in terms of definiteness as in (9).

2. If the adjective describes a non-human plural noun, it is marked for feminine singular (Beeston, 1968, p. 31) and (Ryding, 2005, p. 125) as in (10). That is to say, adjectives are used in their plural forms when they describe plural nouns with the semantic feature +human. Nonetheless, in (11) Ryding, (2005, p. 270) finds that "the plural form of the adjective is used with a nonhuman plural noun." It should be noted that this exception is applied to adjectives describing colors because they have their own distinguished pattern.

10. al-manāzilu al-jadīdatu jamīlatun

the-houses the-new beautiful

The new houses are beautiful.

11. bițāqāt amirkān ixpris alkhựr

cards American express the-green-plu.

Green American express cards

3. If the noun is marked for definiteness and it follows the adjective, the definite prefix is not attached to that adjective as in (12).

12. Garị̣u al-mankabayn (with broad shoulders)

broad the-shoulder-two

The Arabic adjective comparative and superlative forms are made by prefixing $? a$ - changing the vowel pattern for comparative and prefixing the definite article $a l$ - to the comparative form to get the superlative such as qașir, ?aqșar min, al?qșar. The comparative form in Arabic can be used to mean superlative in some cases as in (13). In this case a pronoun suffix is attached to the comparative form.

\section{Man Pasgharukum sinnan?}

who younger-you age

Who is the youngest among you?

\section{English words}

English words consist of one or more morphemes. Bound morphemes in English are either prefixes or suffixes that are attached to the root or the stem. A root in English is a free morpheme that can stand on its own as an independent word. Yet, there are some bound roots that carry no meaning if separated from the free root such as cran, luke and ept in cranberry, lukewarm and inept respectively. Most of the affixes in English are derivational. Derivational affixes can be prefixes or suffixes, but inflectional affixes are always suffixes in English. Inflectional morphemes in English are of seven types: two are suffixed to nouns, plural -s and genitive -'s; two are suffixed to adjectives, comparative -er and superlative -est; and three are suffixed to verbs, third person 
singular number present tense -s, past tense and past participle -ed, and present participle -ing. The following, therefore, is a brief discussion of verb, noun and adjective inflectional morphology.

\subsection{English Verbs}

Grammatical categories that apply to English verbs are: person, number, tense, aspect, voice and mood.

\subsubsection{Person and Number}

When the suffix $-s$ is added to the base form of a verb in English, it indicates third person singular number present tense. Helping verbs, is, does and has refer to third person singular present tense as well. According to (Palmer, 1974, p. 14) and (Miller, 2002, p. 109) the idiosyncratic verb be is the only verb that has a form for the first person singular present tense - am and it is also the only verb that has two distinct forms that mark past tense singular and past tense plural, was and were. The auxiliary are designates first or third person plural and second person singular and plural. The past tense form was is a sign of first person or third person singular number and were (Note 8) shows second person singular and plural and third person plural. Students do make lots of errors in their performance with regard to the use of appropriate form of the verb.

\subsubsection{Tense and Aspect}

Tense refers to the point of time in which the action occurs present, past or future, but aspect denotes whether the action has completed or not. Aspect and tense co-occur in English morphosyntactic structures. Quirk, Greenbaum, Leech \& Svartvik, $(1985$, p. 189) point out that tense is realized morphologically but aspect is realized syntactically. The complete action indicates a perfective aspect and the incomplete action designates the imperfective or progressive aspect. McCarthy, (2002, p. 40) indicates that "a verb lexeme has at most five forms. In fact, most verbs have only four forms, because the past tense and the perfect (or passive) participle forms are the same." Some irregular verbs show three forms such as cut, cuts, cutting because the present, the past and the past participle are the same. The verb to be, on the other hand, exhibits eight forms be, is, am, are, was, were, been and being. Modal verbs do not have participle forms. Consequently, they exhibit only two forms such as shall, should and may, might. Present is recognized by zero inflection or by adding the suffix $-s$ to signify third person singular number (Note 9) and past tense regular forms are recognized by the inflectional past tense morpheme -ed but the future tense is not recognized by inflectional suffixes. Mohammad, (1982, p. 69) says that

Some linguists such as Hockett (1958); Lyons (1968); and Palmer (1974) do not recognize the existence of a future tense in English. Their arguments are based on the assumption that the inflectional morphology of the English verb does not include any affix, whatsoever, that could be regarded as an explicit marker of future tense.

\subsubsection{Voice}

English verbs have active form and passive form. The passive voice in English is a morphosyntactic operation in the sense that the head verb is morphologically changed into its past participle form and is followed by a form of be that indicates tense and aspect and sentence word order is also changed. The passive sentence is simply recognized in English. If the past participle form of the verb is preceded by an auxiliary verb to be or a form of get, the sentence is in its passive form. However, there are structures of be or get followed by the past participle form that are obviously not true passives (Quirk et al., 1985, p. 167) as in (14).

14. a. He was interested in mathematics.

b. He got bored.

According to Chomsky, (1957) active sentences are kernel sentences from which the passive voice is transformed by applying the formula:

$\mathrm{NP} 1$ - V - NP2 $\longrightarrow \mathrm{NP2}-$ be+ en-v — by NP1

By moving the patient from its position to the subject position, inserting a suitable verb to be, changing the head verb into the past participle form, and introducing a prepositional phrase by + the agent which is optional, passive sentences are formed from their active counterparts.

According to Shamsan, (2005, p. 85) the English passive is commonly misunderstood by Arab students. As a result, they make errors when they translate Arabic passive constructions into English.

\subsubsection{Mood}

English verbs can be in the indicative, subjunctive or imperative mood. Indicative mood expresses a fact, assertion or negation as in (15). 
15. a. I will visit my friend tomorrow.

b. He cannot swim.

Subjunctive Mood expresses wishes, doubtful and unreal situations or conditions and indirect advice. Quirk, et al., (1985, p. 155) point out that "there are two forms of the subjunctive, traditionally called the present and past subjunctive." The past subjunctive is often used in clauses that are introduced by if or wish. The past tense plural form (were) is used with $1^{\text {st }}$ and $3^{\text {rd }}$ person singular subjects $I$, he and she as in (16).

16. a. If I were a millionaire, I would buy three cars.

b. I wish I knew the fact.

The simple form of verbs like be, stay etc is used in the subjunctive mood after expressions like it is necessary, it is urgent or in that clauses that are preceded by verbs like recommend, advise, demand, urge, suggest etc. as in (17).

17. The committee recommended that the student be awarded the $\mathrm{PhD}$ degree.

According to Zandvoort, (1962, p. 88) "the subjunctive is further found in a number of traditional phrases" that (Quirk et al., 1985, p. 157) call formulaic subjunctive as in (18).

18. a. Suffice it to say

b. God bless you.

Imperative mood expresses direct commands or requests as in (19).

19. a. Keep quiet.

b. Pass me the salt, please.

\subsection{Nouns}

Nouns in English are marked for number, case and gender.

\subsubsection{Number}

Common nouns in English are either singular or plural. However, dual can be indicated in English by using paired conjunctions like both/and, either/or and neither/nor. The general rule for making nouns in the plural form in English is by adding the plural suffix -s, sometimes -es such as book/books, bus/buses etc. Some nouns undergo modification and then the plural suffix $-s$ is added, e.g. knife/knives. There are nouns that are marked for plural by adding zero morpheme such as deer and sheep. Moreover, some nouns have irregular plural forms, e.g. child/children and index/indices. Irregular nouns such as foot/feet and man/men are made plural by infixing a different vowel.

\subsubsection{Case}

English nouns are marked for genitive case only by adding the genitive marker -'s to the end of singular nouns e.g. elephant's trunk, to nouns that are made plural by adding zero morpheme e.g. sheep's horn, to irregular singular and plural nouns such as child's ball/children's toys, or by adding apostrophe -' to the end of plural regular nouns and to the end of proper nouns that end with -s e.g. for Jesus' sake.

\subsubsection{Gender}

Gender in English is not common and feminine nouns can be found in the following types of nouns:

1. Nouns that refer to family members such as mother, wife, girl, woman, daughter, niece, aunt, grandmother, granddaughter, stepmother, stepdaughter, stepsister.

2. Nouns that refer to human beings in general such as lady, queen, princess, sultana, hostess, actress, waitress, heroine.

3. Names of animals such as cow, heifer, she goat, vixen, tigress, lioness.

In as far as morphology is concerned, Salim, (2013, p. 126) has classified the above mentioned types of nouns as follows:

1. Nouns formed by suppletion such as mother, girl, daughter, niece, aunt and queen whose masculine counterparts are entirely different.

2. Some are formed by adding the suffix -ess such as hostess, princess and lioness.

3. Other nouns are formed by adding other endings such as heroine and sultana. 
4. Others are formed by placing a word before or after as grandmother and stepsister.

However, the words in type number (4) have undergone a word formation rule called compounding.

Quirk and Greenbaum (1973, pp. 90-91) has categorized the personal masculine and feminine nouns into two types: nouns that are morphologically marked for gender such as bridegroom/bride, widower/widow, usher/usherette and emperor lempress and nouns that are not morphologically marked for gender such as father/mother, brother/sister and bachelor/spinster.

\subsection{Pronouns}

Pronouns in English are marked for number, person, gender and case. The following table explains how English pronouns are marked for these categories.

Table 6. Pronoun forms

\begin{tabular}{lllllll}
\hline Pronouns & \multicolumn{7}{l}{ Case } & \multicolumn{5}{l}{} & & \\
\cline { 2 - 4 } Person & Nom. & Acc. & Gen. & & Number & Gender \\
\hline \multirow{3}{*}{ First } & I & Me & My & Mine & Sg. & Masc./Fem. \\
\hline Second & We & Us & Our & Ours & Pl. & Masc./Fem. \\
\hline \multirow{4}{*}{ Third } & You & You & Your & Yours & Sg./Pl. & Masc./Fem. \\
& He & Him & His & His & Sg. & Masc. \\
& She & Her & Her & Hers & Sg. & Fem. \\
& It & It & Its & Its & Sg. & Neu. \\
& They & them & Their & Theirs & Pl. & Masc./Fem./Neu. \\
\hline
\end{tabular}

\subsection{Adjective}

Adjective in English are inflected for comparative and superlative degrees. Adjectives like dead and true are non-gradable adjectives, but adjectives like big and small are gradable. Gradable adjectives "can be used in comparative constructions" (Yule, 1985, p. 117). The inflectional suffixes added to gradable adjectives are -er and -est for the comparative and superlative degrees respectively. Disyllabic adjectives like beautiful are not inflected. They rather take periphrastic forms in their comparative and superlative degrees. More precedes the adjective for comparative and most for superlative. According to Quirk and Greenbaum, (1973, p. 72) "common disyllabic adjectives that can take inflected forms are those ending in unstressed vowel, syllabic $/ 1 /$, or $/ \mathrm{o}(\mathrm{r}) /$ " such as friendly, gentle and clever.

\section{Conclusion}

To sum up, word structure in Arabic and English has been discussed and the main focus was on words that have inflectional forms in the two languages. The parts of speech that have inflectional forms in the two languages are verbs, nouns and adjectives. Analysis of word structures in Arabic and English shows the following:

(1) Arabic content word morphemes are discontinuous and word root is consonantal. Arabic has a root-and-pattern morphology. The root is consonantal and the pattern is the vowel/s affixed to the root, whereas, English morphemes are continuous and word root must have (a) vowel/s.

(2) Inflections can be suffixes or prefixes in Arabic. However, in English they are all suffixes.

(3) Both Arabic and English verbs, nouns, and adjectives have inflectional affixes.

(4) Verbs in Arabic and English are conjugated to indicate tense, person, number and voice. However, English verbs have a fewer person and number distinctions and totally lack gender distinction.

(5) The imperative form of the verb in Arabic has suffixes that designate grammatical categories of number and gender, but in English language, number and gender are not noticed in imperative sentences for the reason that English has only one pronoun for second person.

(6) A verb lexeme in Arabic has three forms: present, past and imperative, but in English most verbs have four forms. These forms are used to express different tenses.

(7) Passive voice in Arabic is a mainly a morphological operation, but in English it is a morphosyntactic process. 
(8) The subjunctive mood is indicated by using the past form of the verb in English or sometimes by using the infinitive form without to. Only the present form of the verb is marked for indicative, subjunctive and jussive mood in Arabic.

(9) Nouns in Arabic are inflected for number, gender, case and definiteness, but English nouns are inflected for number, gender and case only.

(10) Arabic and English share singular and plural in the system of number and Arabic has dual which does not exist in English. The plural in Arabic has three types: sound masculine plural, sound feminine plural and broken plural which is regarded as irregular. In English, the nouns are made plural by adding the suffix $-s$ or -es, or by modification. However, some nouns are irregular.

(11) Gender is common in Arabic nouns and most of the feminine nouns have gender suffix. Some Arabic nouns do not have the feminine marker such as nouns that refer to female people, names of countries/cities and collective nouns. In English, gender is not common, yet it can be found in nouns that refer to human beings or animals. Some English nouns are changed into feminine by adding the suffix -ess; others are changed into feminine via suppletion; and in some other cases feminine nouns are formed by means of compounding.

(12) Nouns in Arabic are inflected for three cases: nominative, accusative and genitive, but English nouns are marked for the genitive case only.

(13) The number of pronouns in Arabic is more than that in English and they are either independent or dependent affixes, but in English they are all independent. Pronouns in both Arabic and English are marked for person, number, gender and case.

\section{Implications}

This study has some important implications for English language teachers and educators. Findings of this study could highlight some of the problematic areas that are likely to face Arab learners of English morphology. Such problems can carefully be dealt with in the textbooks and teachers can have their teaching plans properly worked out to overcome these problems. Students, on the other hand, will be more aware of the differences between their language and the target language and they would be in a better position to learn it.

\section{Recommendations for Further Research}

This study has by-and-large been a theoretical research, yet still, it has yielded some interesting and useful results. However, for more benefit, an empirical study needs to be conducted to verify the findings of this current study. Furthermore, some other studies that contrast the syntax and semantics of Arabic and English have to be performed. Findings of these studies could give both teachers and textbook writers lots of insights into the nature of these languages and on how to tackle problematic linguistic issues related to language learning.

\section{References}

Al-Naḥās, M. (1995). Min Qa đ̣āya Al-Lughah. Kuwait: Kuwait University.

Beeston, A. F. (1968). Written Arabic: An Approach to the Basic Structures. New York: Cambridge University Press.

Chomsky, N. (1957). Syntactic Structures (2nd ed). Berlin, New York: Mouton de Gruyter.

Fehri, A. (2012). Key Features and Parameters in Arabic Grammar. The Netherlands: John Benjamins Publishing Co. http://dx.doi.org/10.1075/la.182

Fisiak, J. (Ed.). (1981). Contrastive Linguistics and the Language Teacher. Oxford: Pergamon Press Ltd. http://dx.doi.org/10.1075/cilt.12

Haywood \& Nahmad, (1965). A New Arabic Grammar of the Written Language. London: Lund Humphries.

McCarthy, A. (2002). An Introduction to English Morphology: Words and Their Structure. Edinburgh: Edinburgh University Press.

Miller, J. (2002). An Introduction to English Syntax. Edinburgh: Edinburgh University Press.

Mohammad, M. D. (1982). The Semantics of Tense and Aspect in English and Modern Standard Arabic. (Doctoral Dissertation). University Microfilms International 300 N. Zeeb Road, Ann Arbor, M I 48106.

Palmer, F. R. (1974). The English Verb (2nd ed.). London and New York: Longman.

Quirk, R. et al. (1985). A Comprehensive Grammar of the English Language. London and New York: Longman.

Quirk, R., \& Greenbaum, S. (1973). A University Grammar of English. London: Longman. 
Ryding, K. C. (2005). A Reference Grammar of Modern Standard Arabic. New York: Cambridge University Press. http://dx.doi.org/10.1017/CBO9780511486975

Salim, J. A. (2013). A Contrastive Study of English-Arabic Noun Morphology. International Journal of English Linguistics, 3, 122-132. http://dx.doi.org/10.5539/ijel.v3n3p122

Shamsan, M. (2005). The Passive Voice in Arabic and English (Unpublished Master's Thesis). Taiz University, Yemen.

Spencer, A. (1991). Morphological Theory: An Introduction to Word Structure in Generative Grammar. USA: Blackwell.

Thackston, W. M. (1994). An Introduction to Koranic and Classical Arabic: An Elementary Grammar of the language. Maryland: IBEX Publishers.

Thakur, D. (1997). Linguistic Simplified: Morphology. Patna: BharatiBhawan.

Waston, J. (2002). The Phonology and Morphology of Arabic. New York: Oxford University Press.

Wright, W. (1967). A Grammar of the Arabic Language. Cambridge: Cambridge University Press.

Yule, G. (1985). The Study of Language (4th ed.). New York: Cambridge University Press.

Zandvoort, R. W. (1962). A Handbook of English Grammar (7th ed.). London: Longman Group Limited.

\section{Notes}

Note 1. Arabic alphabet transliteration has been taken from the ALA (American Library Association) except for hamza and ayn from IPA.

Note 2. Different kinds of particles are used before the present or the past tense form of the verb to indicate different tenses in Arabic.

Note 3. If the present tense form ends with a long vowel, it is changed into its short vowel counterpart to mark the verb for the jussive mood.

Note 4. There are exceptions to this rule. See (Shamsan, 2005).

Note 5. English native speakers who study Arabic are familiar with two categories for number: singular and plural only. They may find problems with the dual category.

Note 6. There are exceptions to this rule such as the word Cașā 'a stick' becomes Cașawān 'two sticks' in its dual form.

Note 7. Pronouns can be prefixed to the present form of the verb in Arabic only.

Note 8. In adverbial clauses introduced by if, though, as if, as though and in nominal clauses after wish and suppose, the form subjunctive were is used to indicate $1^{\text {st }}$ and $3^{\text {rd }}$ person singular of the past tense (Quirk, 1985, p. 158).

Note 9. Suffixes are not added to auxiliary verbs. Verbs to be, to have and modals are regarded as irregular verbs to which the $3^{\text {rd }}$ person singular number present tense marker $-s$ is not added. The present forms is and has are used to mark agreement with the $3^{\text {rd }}$ person singular number subject.

\section{Copyrights}

Copyright for this article is retained by the author(s), with first publication rights granted to the journal.

This is an open-access article distributed under the terms and conditions of the Creative Commons Attribution license (http://creativecommons.org/licenses/by/3.0/). 